
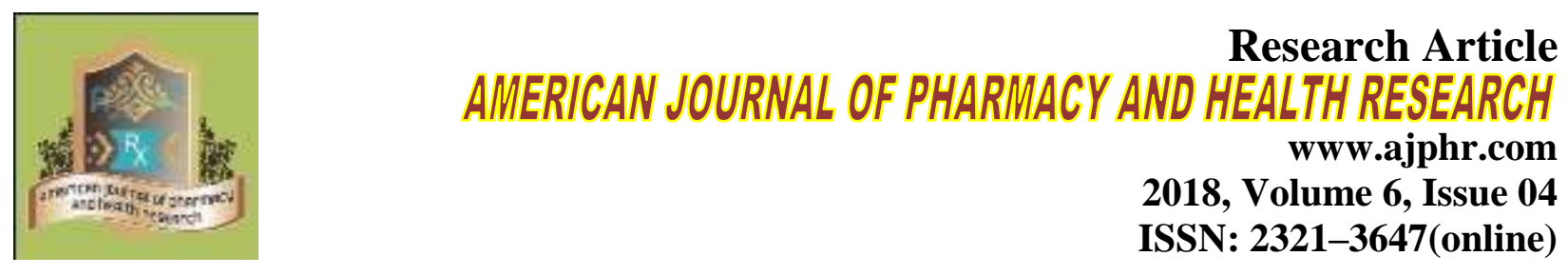

\title{
Spectrophotometric Determination of Amphetamine In Pure and Pharmaceutical Formulations
}

\author{
B. Eswara Naik ${ }^{1,3}$, C. Narasimha Rao ${ }^{2}$, S. Ramanaiah ${ }^{1}$ and P. Venkateswarlu ${ }^{2 *}$ \\ 1.Department of Chemistry, Rayalaseema University, Kurnool, 518002, Andhra Pradesh, India. \\ 2.Department of Chemistry, S. V. University, Tirupati, 517502, Andhra Pradesh, India. \\ 3.Department of Chemistry, IIIT-R.K.Valley, RGUKT-AP., Kadapa, 516330, Andhra Pradesh, \\ India.
}

\begin{abstract}
A simple, sensitive and rapid spectrophotometric method has been developed for the estimation of Amphetamine (AM) in bulk and in pharmaceutical formulations using 2,3-dichloro-5,6dicyano-p-benzoquinone (DDQ). The proposed method is based on the formation of chargetransfer complex between AM and DDQ. AM in the presence of DDQ formed pale wine red color complex which showed a maximum absorbance at $465 \mathrm{~nm}$ against the blank. The limit of detection and quantitation were $0.1395 \mathrm{mg} / \mathrm{ml}$ and $0.4644 \mathrm{mg} / \mathrm{ml}$ respectively. The results of analysis were validated by recovery studies, accuracy, precision, LOD, LOQ, robustness and ruggedness, which indicated that the present method can be successfully applied for the determination of AM in pure and in pharmaceutical formulations.
\end{abstract}

Keywords: Spectrophotometric method, Amphetamine, Charge-transfer complex, DDQ. 


\section{INTRODUCTION}

Amphetamine (AM); 1-phenylpropan-2-amine (Figure. 1) is a potent central nervous system (CNS) stimulant of the phenylamine class and is a synthetic stimulant. It is used in the treatment of attention deficit hyperactivity disorder (ADHD), narcolepsy and obesity. AM is also used as an athletic performance enhancer, cognitive enhancer and recreationally as an aphrodisiac, euphoriant $^{1-4}$. In the literature, several analytical methods have been reported for the determination of the AM, which include paper chromatography ${ }^{5}$, thin layer chromatography ${ }^{6-10}$, high performance liquid chromatography ${ }^{11-15}$, gas chromatography ${ }^{16-20}$, colorimetry ${ }^{21-24}$ and spectrophotometry $^{25,26}$. The survey of literature has shown that no spectrophotometric method was reported so far, for the determination of AM with DDQ. In the present paper, a new spectrophotometric method has been reported for the determination of AM based on chargetransfer complex reaction with DDQ, which gave a coloured solution. The proposed method is cost-effective, sensitive, rapid, accurate and reproducible and it can be used for the determination of $\mathrm{AM}$ in pure and in pharmaceutical formulations.

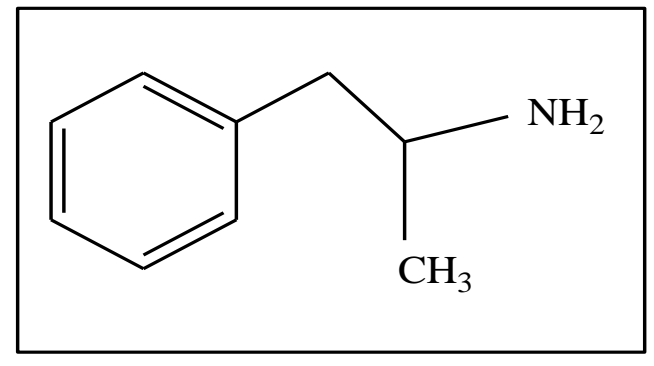

Figure 1: Structure of AM

\section{EXPERIMENTAL}

\section{Instrumentation}

A Shimadzu UV-Visible spectrophotometer (UV-160A) with a matched pair of $10 \mathrm{~mm}$ quartz cell was utilized for all measurements. Mettler Toledo analytical balance (accuracy $0.1 \mathrm{mg}$ ) was used for weighing all the samples.

\section{Materials and Reagents}

AM was procured from Sigma-Aldrich. Formulations were purchased from local market. All the used chemicals were analytical reagent grade. Double distilled water is used throughout the experiment. A stock solution of AM was prepared by dissolving accurately weighed $100 \mathrm{mg}$ of pure drug in $100 \mathrm{ml}$ of methanol and sonicated to get required concentration of $1 \mathrm{mg} / \mathrm{ml}$. From this, further dilutions were made with double distilled water to get required concentrations and used for current investigation. 


\section{RESULTS AND DISCUSSION}

\section{Absorption spectrum}

Several aliquots of standard solutions of AM were taken in volumetric flasks, $2.8 \mathrm{ml}$ of $0.2 \%$ DDQ solution was added into each volumetric flask and solution was made up to the mark by using corresponding solvent. After the mixing of the above solutions, a pale wine red colour developed, which showed a maximum absorbance at $465 \mathrm{~nm}$ against blank (Figure. 2).

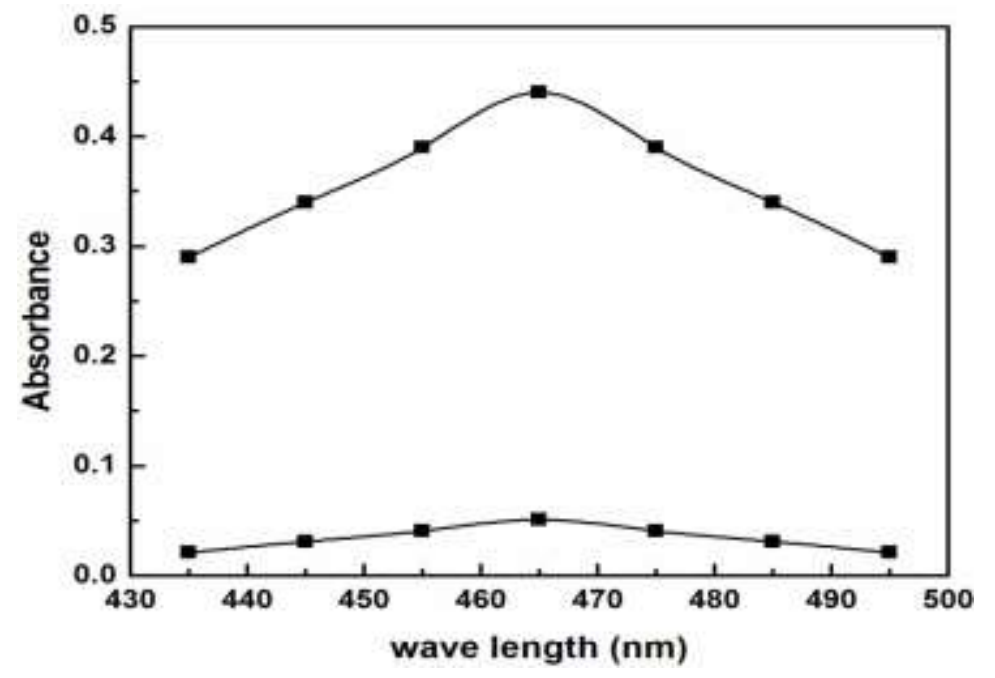

Figure 2: Absorption spectrum of AM with DDQ

\section{Effect of DDQ concentration}

To know the effect of DDQ concentration, standard solution of AM was allowed to react with different volumes of $0.2 \%$ DDQ, viz. 0.4, 0.8, 1.2, 1.6, 2.0, 2.4, 2.8 and $3.2 \mathrm{ml}$. The results showed that the maximum absorbance was obtained with $2.8 \mathrm{ml}$. Hence, $2.8 \mathrm{ml} 0.2 \%$ DDQ was used for the determination of the drug.

\section{Effect of the concentration of drug}

The absorbance spectrum was measured for various concentrations of AM solutions in the range of $4-44 \mu \mathrm{g} / \mathrm{ml}$ with addition of $2.8 \mathrm{ml}$ of $0.2 \%$ DDQ solution at wave length of $465 \mathrm{~nm}$ against blank. The obtained results obeyed Beer's law.

\section{Effect of the solvent}

Different non-polar solvents were investigated in order to select the suitable solvent for the analysis of drug. These solvents include chloroform, methanol, 1, 2-dichloroethane, acetonitrile and acetone. It is found that methanol is considered to be an ideal solvent for this experiment and that exhibited a maximum optical density when compared to other solvents.

\section{Analytical method validation}

\section{Linearity}


Linearity of the AM solution was studied and calibration plots were constructed with obtained results (Figure. 3). The linearity of calibration graphs was proved by the high values of the correlation coefficient and the small values of the y-intercept of the regression equation. The apparent molar absorptivity's of the resulting coloured complexes and relative standard deviation of response factor for proposed spectrophotometric method were also calculated. The obtained results like Beer's law limit, Sandell's sensitivity, molar absorptivity, correlation coefficient were reported in Table 1.

Table 1: Spectral characteristics of the drug with reagent

\begin{tabular}{|c|c|c|c|c|c|c|c|c|c|c|}
\hline $\begin{array}{l}\lambda \mathrm{ma} \\
\mathbf{x} \\
(\mathrm{nm})\end{array}$ & $\begin{array}{l}\text { Beer's law } \\
\text { limit } \\
(\mu \mathrm{g} / \mathrm{ml})\end{array}$ & $\begin{array}{l}\text { Molar } \\
\text { absorbance } \\
\left(\text { L.mol } \mathbf{c m}^{-1}\right)\end{array}$ & $\begin{array}{l}\text { Sandell's } \\
\text { sensitivit } \\
\mathbf{y}\end{array}$ & $\begin{array}{l}\text { Correlation } \\
\text { coefficient } \\
\left(\mathbf{r}^{2}\right)\end{array}$ & $\begin{array}{l}\text { Slop } \\
\text { e } \\
\text { (m) }\end{array}$ & $\begin{array}{l}\text { Interc } \\
\text { ept } \\
\text { (c) }\end{array}$ & $\begin{array}{l}\% \\
\text { RS } \\
\text { D }\end{array}$ & $\begin{array}{l}\text { Colou } \\
\mathbf{r}\end{array}$ & $\begin{array}{l}\mathbf{L} \\
\mathbf{O} \\
\mathbf{D}\end{array}$ & $\begin{array}{l}\mathbf{L} \\
\mathbf{O} \\
\mathbf{Q}\end{array}$ \\
\hline \multirow[t]{3}{*}{410} & $6-27$ & $2.698 \times 10^{4}$ & 0.0017 & 0.9925 & 0.25 & 0.044 & 0.1 & Yellow & 0.1 & 0.3 \\
\hline & & & & & 4 & 7 & 724 & ish & 18 & 94 \\
\hline & & & & & & & & Red & 3 & 0 \\
\hline
\end{tabular}

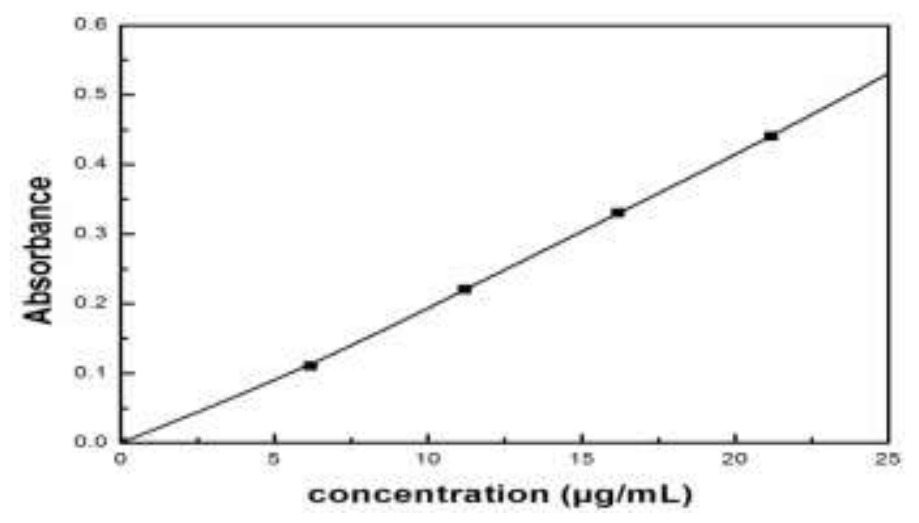

Figure 3: Calibration plot of AM

\section{Robustness and ruggedness}

In the evaluation of the robustness, some parameters like drug concentration, reagent concentration, wavelength range and shaking time were interchanged. The capacity remains unaffected. Method ruggedness was expressed as RSD \% of the same procedure applied by two analysts and in two different instruments on different days. The results showed no statistical difference between different analysts and instruments suggesting that the developed methods were robust and rugged.

\section{Accuracy}

The accuracy of an analytical method is the nearness in conformity between the established exact value or reference value and the experimental value. Accurate results proved that the recovery values in drug and in pharmaceutical forms are within the acceptance criteria and details were presented in Table 2 and 3. 


\section{Precision}

Precision of a method is a measure of the ability to create reproducible results. It is evaluated using six separate determinations. The intra and inter day precision were evaluated and found RSD \% less than 1.0, which indicates that there is no significant variations for intra and inter day analysis. These results were presented in Table 2 and 3.

Table 2: Evaluation of accuracy and precision results of the proposed method in bulk form

\begin{tabular}{|c|c|c|c|c|c|c|c|c|}
\hline $\begin{array}{l}\text { Taken } \\
\text { mg/ml }\end{array}$ & $\begin{array}{l}\text { Intra day } \\
\text { *Found } \\
\text { mg/ml }\end{array}$ & $\begin{array}{l}\text { Recovery } \\
\%\end{array}$ & $\pm \mathbf{S D}$ & $\begin{array}{l}\% \\
\text { RSD }\end{array}$ & $\begin{array}{l}\text { Inter day } \\
\text { *Found } \\
\text { mg/ml }\end{array}$ & $\begin{array}{l}\text { Recovery } \\
\%\end{array}$ & $\pm \mathbf{S D}$ & $\begin{array}{l}\% \\
\text { RSD }\end{array}$ \\
\hline 2 & 1.98 & 99.00 & 0.010 & 0.51 & 1.97 & 98.67 & 0.006 & 0.29 \\
\hline 4 & 3.97 & 99.25 & 0.010 & 0.25 & 3.97 & 99.33 & 0.012 & 0.29 \\
\hline 6 & 5.98 & 99.67 & 0.010 & 0.17 & 5.96 & 99.33 & 0.010 & 0.17 \\
\hline
\end{tabular}

*Average of six determinations

Table 3 Evaluation of accuracy and precision results of the proposed method in pharmaceutical dosage form

\begin{tabular}{|c|c|c|c|c|c|c|c|c|c|}
\hline $\begin{array}{l}\text { Pharma- } \\
\text { ceutical } \\
\text { formulation }\end{array}$ & $\begin{array}{l}\text { Taken } \\
\text { mg/ml }\end{array}$ & $\begin{array}{l}\text { Intra daj } \\
\text { *Found } \\
\mathrm{mg} / \mathrm{ml}\end{array}$ & $\begin{array}{l}\text { Recove } \\
\text { ry \% }\end{array}$ & $\pm \mathrm{SD}$ & $\begin{array}{l}\% \\
\text { RSD }\end{array}$ & $\begin{array}{l}\text { Inter day } \\
\text { *Found } \\
\text { mg/ml }\end{array}$ & $\begin{array}{l}\text { Recove } \\
\text { ry \% }\end{array}$ & \pm SD & $\begin{array}{l}\% \\
\text { RSD } \\
\end{array}$ \\
\hline adderall & 4 & 3.94 & 98.50 & 0.020 & 0.51 & 3.96 & 99.08 & 0.006 & 0.15 \\
\hline Adderal XR & 6 & 5.97 & 99.56 & 0.012 & 0.19 & 5.97 & 99.50 & 0.010 & 0.17 \\
\hline mydayis & 8 & 7.92 & 99.00 & 0.040 & 0.51 & 7.96 & 99.50 & 0.026 & 0.33 \\
\hline
\end{tabular}

\section{Recovery}

Recovery studies were carried out by using standard addition method. The results are summarized in Table 4.

\section{Limit of Detection (LOD)}

The detection limit of an individual analytical procedure is the lowest amount of analyte in a sample which can be detected but not necessarily quantitated as an exact value.

The LOD was calculated by using the following formula.

$$
L O D=\frac{3.3 \mathrm{~s}}{\mathrm{~S}}
$$

Where $s=$ Standard deviation of the response

$$
\mathrm{S}=\text { Slope of the calibration curve }
$$

\section{Limit of Quantitation (LOQ)}

The quantitation limit of an individual analytical procedure is the lowest amount of analyte in a sample which can be quantitatively determined with suitable precision and accuracy.

The LOQ was calculated by using the following formula. 


$$
L O Q=\frac{10 \mathrm{~s}}{\mathrm{~S}}
$$

Where $s=$ Standard deviation of the response

$$
\mathrm{S}=\text { Slope of the calibration curve }
$$

\section{APPLICATIONS}

The proposed method is applied for the determination AM in available pharmaceutical formulations in market drug and the results are given in Table 3.

Blood and urine samples were collected from healthy volunteers. The samples were centrifuged at $3000 \mathrm{rpm} \min ^{-1}$ for 10 minutes. The solutions were filtered and preserved in the absence of light at $4^{0} \mathrm{C}$. To this, various concentrations of AM samples were added and analyzed by the developed method. The results are given in Table 4.

Table 4 Method accuracy from recovery studies

\begin{tabular}{llllll}
\hline Sample & $\begin{array}{l}\text { Added } \\
\mathbf{m g} / \mathbf{m l}\end{array}$ & $\begin{array}{l}\text { *Found } \\
\mathbf{m g} / \mathbf{m l}\end{array}$ & Recovery \% & $\mathbf{\pm S D}$ & \%RSD \\
\hline Blood samples & 0.2 & 0.20 & 98.50 & 0.000 & 0.00 \\
& 0.4 & 0.40 & 99.25 & 0.001 & 0.25 \\
& 0.6 & 0.59 & 99.06 & 0.003 & 0.42 \\
Urine samples & 0.8 & 0.79 & 98.63 & 0.007 & 0.89 \\
& 0.4 & 0.40 & 99.08 & 0.002 & 0.39 \\
& 0.6 & 0.60 & 99.39 & 0.002 & 0.35 \\
& 0.8 & 0.79 & 99.29 & 0.005 & 0.59 \\
& 1.0 & 0.98 & 98.33 & 0.012 & 1.17 \\
\hline
\end{tabular}

*Average of six determinations

\section{CONCLUSION}

In the present reported method, the drug AM was estimated in bulk, in pharmaceutical formulations and in biological fluid samples. The linearity of the proposed method was good from the result of correlation coefficient. The developed method is novel, simple, specific, accurate, precise and reproducible. Specificity and selectivity, LOD, LOQ, molar absorptivity and Sandell's sensitivity values indicate that the proposed analytical method can be successfully utilized for the estimation of AM in bulk, in pharmaceutical formulations and in biological fluid samples.

\section{REFERENCES}

1. Nestler EJ, Hyman SE, Holtzman DM, Malenka RC. Molecular neuropharmacology. A foundation for clinical neuroscience. New York Mc Graw. Hill. 2015; 3.

2. Heal DJ, Smith SL, Gosden J, Nutt DJ. Amphetamine, past and present-a pharmacological and clinical perspective. J. Psychopharmacol. 2013; 27(6): 479-496. 
3. Sulzer D, Sonders MS, Pulsen NW, Galli A. Mechanisms of neurotransmitter release by amphetamines: a review. Prog. Neurobiol. 2005; 75(6): 406-433.

4. de la Torre R, Farre M, Navarro M, Paciffici R, Zuccaro P, Pichini S. Clinical pharmacokinetics of amphetamine and related substances: monitoring in conventional and non-conventional matrices. Clin. Pharmacokinet. 2004; 43(3): 157-185.

5. Wickstrom A, Salvesen B. The separation and identification of some sympathomimetic amines by paper partition chromatography. J. Pharm. Pharmacol. 1952; 4(9): 631-635.

6. Zakrzewska A, Parczewski A, Kazmierczak D, Ciesielki W, Kochana J. Visualization of amphetamine and its analogues in TLC. Acta. Chim. Slov. 2007; 54: 106-109.

7. 7.Brien BA, Bonicamp JM, Jones DW. Differntiation of amphetamine and its major hallucinogenic derivatives using thin-layer chromatography. J. Anal Toxicol. 1982; 6(3): 143-147.

8. Wolff K, Sanderson MJ, Hay AW. A rapid horizontal TLC method for detecting drugs of abuse. Ann. Clin. Biochem. 1990; 27(5): 482-488.

9. Choulis NH. Analysis of amphetamine in urine using TLC and interference refractometry. Biochemical Medicine. 1971; 5(4): 311-316.

10. Kato N, Fujita S, Ohta H, Fukuba M, Toriba A, Hayakawa K. Thin layer chromatography/fluorescence detection of 3,4-methylaminedioxy-methamphetamine and related compounds. J. Forensic Sci. 2008; 53(6): 1367-1371.

11. Sadeghipour F, Giroud C, Rivier L, Veuthey JL. Rapid determination of amphetamines by high-performance liquid chromatography with UV detection. J. Pharmatography A. 1997; 761(1-2): 71-78.

12. Hendrickson HP, Milesi-Halle A, Laurenzana EM, Owens SM. Development of a liquid chromatography-tandem mass spectrometric method for the determination of methamphetamine and amphetamine using small volumes of rat serum. J. Chromatogr B analyt. Technol. Biomed. Life Sci. 2004; 806(2): 81-87.

13. Sultan M. Simultaneous HPLC determination and validation of amphetamine, methamphetamine, caffeine, paracetamol and theophylline in illicit seized tablets. Int. J. Pharm. Pharm. Sci. 2014; 6(4): 294-298.

14. Pavlova V, Petrovska-Jovanovic S. Simultaneous determination of amphetamine, methamphetamine and caffeine in seized tablets by high-performance liquid chromatography. Acta. Chromatographica. 2007; 18(2): 157-167. 
15. Soares ME, Carvalho M, Carmo H, Remiao F, Carvalho F, Bastos ML. Simultaneous determination of amphetamine derivatives in human urine after SPE extraction and HPLC-UV analysis. Biomed. Chromatogr. 2004; 18(2): 125-131.

16. Wozniak MK, Wiergowski M, Aszyk J, Kubica P, Namiesnik J, BIziuk M. Application of gas chromatograpgy-tandem mass spectrometry for the determination of amphetaminetype stimulants in blood and urine. J. Pharm. Biomed. Anal. 2018; 148: 58-64.

17. Ondra P, Valka I, Knob R, Ginterova P, Maier V. Analysis of amphetamine-derived designer drugs by gas chromatography with mass spectrometry. J. Ana.l Toxicol. 2015; 40(1): 78-85.

18. Mariotti Kde C, Schuh RS, Ferranti P, Ortiz RS, Souza DZ, Pechansky F, Froehlich PE, Limberger RP. Simultaneous analysis of amphetamine-type stimulants in plasma by solid-phase microextraction and gas chromatography-mass spectrometry. J. Ana.l Toxicol. 2014; 38(7): 432-437.

19. Dobos A, Hidvegi E, Somogyi GP. Comparison of five derivatizing agents for the determination of amphetamine-type stimulants in human urine by extractive acylation and gas chromatography-mass spectrometry. J. Anal. Toxicol. 2012; 38(5): 340-344.

20. Valentine JL, Kearns GL, Sparks C, Letzig LG, Valentine CR, Shappell SA, Neri DF, DeJohn CA. GC-MS determination of amphetamine and methamphetamine in human urine for 12 hours following oral administration of dextro-methamphetamine: lack of evidence supporting the established forensic guidelines for methamphetamine confirmation. J. Anal. Toxicol. 1995; 19(7): 581-590.

21. Argenta-Garcia A, Jornet-Martinez N, Herraez-Hernandez R, Campins-Falco P. A solid colorimetric sensor for the analysis of amphetamine-like street samples. Anal. Chim. Acta. 2016; 943: 123-130.

22. Frings CF, Queen C, Foster LB. Improved colorimetric method for assay of amphetamines in urine. Clin. Chem. 1971; 17(10): 1016-1019.

23. Choodum A, Daeid NN. Digital image-based colorimetric tests for amphetamine and methylamphetamine. Drug Test. Anal. 2011; 3(5): 277-282

24. Fontani F, Morandini F. Colorimetric determination of amphetamine salts in dosage forms. J. Pharm. Pharmacol. 1970; 22(6): 411-413.

25. Wallace JE, Biggs JD, Ladd SL. Determination of amphetamine by ultraviolet spectrophotometry. Anal. Chem. 1968; 40(14): 2207-2210. 
26. Molins CL, Campins PF, Sevillano AC. Extractive-spectrophotometric determination of amphetamine in urine samples with sodium 1,2-naphthoquinone-4-sulphonate. Anal. Chim. Acta. 1993; 283(1): 635-644.

\section{AJPHR is}

Peer-reviewed

monthly

Rapid publication

Submit your next manuscript at editor@ajphr.com / editor.ajphr@gmail.com 